with methotrexate (MTX) was observed in $48 \%$ and with others classic DMARDs in $30 \%$, while $22,3 \%$ received rituximab monotherapy. First-line rituximab option was justified by lung involvement in $21 \%$, past malignancy in $13 \%$, recurrent infections in 5\%, congestive cardiac failure in 3\%, vascular involvement in 3\% and untreated latent tuberculosis in $3 \%$. In the group previously exposed to biologics, $13 \%$ switched therapy due to ineffectiveness and $87 \%$ due to adverse events. No significant differences were found between the 2 groups in terms of age, gender, concomitant use of MTX and baseline DAS28. The group previously exposed to biologics had a longer disease duration (mean 23 vs 15 years, $\mathrm{p}=0.001$ ) and fewer patients with ACPA seropositivity $(79 \%$ vs $97 \%, p=0.035)$. There was a significant reduction of DAS28 at 6,12 and 18 months ( $p<0.001$ for all). Fifty six percent of the patients achieved a EULAR response at 6 months, $46 \%$ at 12 months and $59 \%$ at 18 months. DAS28 variation at 6 months differed significantly between groups, with a better clinical response in naive biological patients comparing to those previously exposed to biologics (median 1.173 vs $0.477 ; p=0.038$ ). There were no differences in terms of DAS28 variation at 12 and 18 months $(p=0.642$ and $p=0.135$, respectively) and in EULAR responses at 6,12 and 18 months between the groups $(p=0.289, p=0.523$ and $p=1.000$, respectively).

Conclusions: Our study confirms the effectiveness of rituximab in RA patients and suggests a higher magnitude of response in naive biological patients at 6 months of RTX therapy. These findings put in perspective an extension of rituximab as a first-line biologic for RA treatment.

Disclosure of Interest: None declared

DOI: 10.1136/annrheumdis-2017-eular.4494

\section{SAT0212 SARILUMAB DOSE REDUCTION IN AN OPEN-LABEL EXTENSION STUDY IN RA PATIENTS WITH INADEQUATE RESPONSE TO TNF INHIBITORS}

R. Fleischmann ${ }^{1}$, P. Hrycaj ${ }^{2}$, H. van Hoogstraten ${ }^{3}$, E.K. Mangan ${ }^{4}$, Y. Lin ${ }^{3}$, S. Jayawardena ${ }^{3}$, G.R. Burmester ${ }^{5} .{ }^{1}$ Metroplex Clinical Research Center, University of Texas Southwestern Medical Center, Dallas, United States; ${ }^{2}$ Department of Rheumatology and Clinical Immunology, Poznań University of Medical Sciences, Poznań, Poland; ${ }^{3}$ Sanofi Genzyme, Bridgewater; ${ }^{4}$ Regeneron Pharmaceuticals, Inc, Tarrytown, United States; ${ }^{5}$ Charité - University Medicine Berlin, Free University and Humboldt University Berlin, Berlin, Germany

Background: Sarilumab is a human mAb blocking the IL-6R $\alpha$. In the phase 3 TARGET study (NCT01709578), sarilumab (150 or $200 \mathrm{mg} \mathrm{SC} \mathrm{q2w)} \mathrm{+}$ csDMARDs demonstrated efficacy in adults with active, moderate-to-severe RA and inadequate response or intolerance to $\geq 1 \mathrm{TNFi}$. Infections, neutropenia, injection site reactions, increased lipids, and increased transaminases were among the most common TEAEs. EXTEND (NCT01146652) is an open-label extension study evaluating long-term safety and efficacy of sarilumab in patients from the sarilumab clinical development program.

Objectives: To examine the effects of dose reduction of sarilumab $200 \mathrm{mg}$ q2w to $150 \mathrm{mg}$ q2w in patients from TARGET that occurred in EXTEND primarily for protocol-specified laboratory abnormalities.

Methods: Patients were switched to or initiated on sarilumab $200 \mathrm{mg}$ q2w after enrolling in EXTEND. Per protocol, investigators could reduce the sarilumab dose from $200 \mathrm{mg} \mathrm{q} 2 \mathrm{w}$ to $150 \mathrm{mg} \mathrm{q} 2 \mathrm{w}$ for $\mathrm{ANC} \geq 0.5$ to $1.0 \mathrm{Giga} / \mathrm{L}$, platelet count $\geq 50$ to $100 \mathrm{Giga} / \mathrm{L}$, or $\mathrm{ALT} \geq 3$ to $5 \times \mathrm{ULN}$. Dose reductions were also performed at the investigator's discretion. Efficacy data from EXTEND were analyzed before and 24 weeks after dose reduction.

Results: As of the July 2016 interim analysis $(\mathrm{N}=452)$, dose reduction from sarilumab $200 \mathrm{mg}$ q2w to $150 \mathrm{mg}$ q2w had occurred in $14.6 \%$ of patients $(n=66)$ from TARGET. The most common reasons for dose reduction were decreased ANC $(8.8 \% ; n=40)$ and increased ALT $(3.3 \% ; n=15)$. At the time of analysis, $80.3 \%$ of patients $(n=53)$ whose dose was reduced were continuing treatment, with a median treatment duration of 1.6 years after dose reduction. Improvements in ANC and ALT were observed over the 6 months after dose reduction (Table 1). Efficacy was maintained 24 weeks after dose reduction (Table 2).

Table 1. ANC and ALT After Dose Reduction ${ }^{\mathrm{a}}$

\begin{tabular}{lcc}
\hline & $\begin{array}{c}\text { Before dose reduction } \\
\mathrm{n}(\%)\end{array}$ & $\begin{array}{c}6 \text { months after dose reduction } \\
\mathrm{n}(\%)\end{array}$ \\
\hline $\begin{array}{c}\text { ANC } \\
\geq 0.5 \text { to }<1.0 \text { Giga/L }\end{array}$ & $25 / 40(62.5)$ & $5 / 39(12.8)$ \\
$<0.5 \mathrm{Giga} / \mathrm{L}$ & 0 & 0 \\
ALT & $13 / 15(86.7)$ & $1 / 13(7.7)$ \\
$>3$ to $\leq 5 \times$ ULN & $1 / 15(6.7)$ & 0 \\
$>5$ to $\leq 10 \times$ ULN &
\end{tabular}

$\bar{a}$ Denominator represents patients who dose reduced because of decreased ANC or increased ALT who had ANC/ALT measured within specified time point.

Table 2. Efficacy After Dose Reduction

\begin{tabular}{lcc}
\hline & $\begin{array}{c}\text { Before dose reduction } \\
(\mathrm{N}=60)\end{array}$ & $\begin{array}{c}6 \text { months after dose reduction } \\
(\mathrm{N}=53)\end{array}$ \\
\hline ACR20 response rate, $\mathrm{n}(\%)$ & $49(81.7)$ & $43(81.1)$ \\
$\Delta \mathrm{HAQ}-\mathrm{DI}$, mean (SD) & $-0.7(0.6)$ & $-0.8(0.7)$ \\
$\Delta \mathrm{DAS28}-\mathrm{CRP}$, mean $(\mathrm{SD})$ & $-3.0(1.2)$ & $-3.0(1.3)$ \\
$\Delta \mathrm{CDAl}$, mean $(\mathrm{SD})$ & $-28.4(12.5)$ & $-28.6(14.6)$ \\
\hline
\end{tabular}

Conclusions: In patients from TARGET whose sarilumab dose was reduced from $200 \mathrm{mg} \mathrm{q} 2 \mathrm{w}$ to $150 \mathrm{mg}$ q2w during EXTEND, there was an improvement in laboratory abnormalities and continuation of treatment for the majority of patients. Improvements in signs and symptoms of RA and physical function were maintained after dose reduction.

Acknowledgements: This study was sponsored by Sanofi Genzyme and Regeneron Pharmaceuticals, Inc. Editorial support was provided by MedThink SciCom and funded by Sanofi Genzyme and Regeneron Pharmaceuticals, Inc

Disclosure of Interest: R. Fleischmann Grant/research support from: AbbVie, Amgen, Ardea Biosciences, Bristol-Myers Squibb, Celgene, GlaxoSmithKline, Eli Lilly, Pfizer, Roche, Sanofi, and UCB, Consultant for: AbbVie, Akros Pharma, Amgen, AstraZeneca, Bristol-Myers Squibb, Janssen, Eli Lilly, Pfizer, Roche, and UCB, P. Hrycaj Consultant for: Pfizer, Celltrion, and Egis, H. van Hoogstraten Shareholder of: Sanofi Genzyme, Employee of: Sanofi Genzyme, E. Mangan Shareholder of: Regeneron Pharmaceuticals, Inc, Employee of: Regeneron Pharmaceuticals, Inc, Y. Lin Shareholder of: Sanofi Genzyme, Employee of: Sanofi Genzyme, S. Jayawardena Shareholder of: Sanofi Genzyme, Employee of: Sanofi Genzyme, G. Burmester Grant/research support from: AbbVie, BristolMyers Squibb, Medlmmune, Merck, Pfizer, Roche, and UCB, Consultant for: AbbVie, Bristol-Myers Squibb, Medlmmune, Merck, Pfizer, Roche, and UCB, Speakers bureau: AbbVie, Bristol-Myers Squibb, Merck, Pfizer, Roche, and UCB DOI: 10.1136/annrheumdis-2017-eular.5155

\section{SAT0213 LOW DOSE IL-2 RESTORES DECREASED ABSOLUTE NUMBER OF REGULATORY T CELLS AND IMBALANCE BETWEEN TH17 AND REGULATORY T CELLS IN PATIENTS WITH RHEUMATOID ARTHRITIS}

R. Jia ${ }^{1}$, X. Li ${ }^{1}$, C. Wang ${ }^{1}$, C. Gao ${ }^{2} .{ }^{1}$ The Department of Rheumatology, the Second Hospital of Shanxi Medical University, Taiyuan, China; ${ }^{2}$ Pathology, Joint Program in Transfusion Medicine, Brigham and Women's Hospital/Children's Hospital Boston, Harvard Medical School, Boston, United States

Background: A therapeutic revolution in the past decade is still a considerable unmet need in the treatment of rheumatoid arthritis (RA). On the other hand, dysfunction of regulatory $T$ cells (Tregs) has been considered to be a pivotal cause of RA and correction of this dysfunction to be a potential RA therapy 1 . However, abnormalities of Tregs in patients with RA were reported controversially in previous studies ${ }^{2}$, in which only proportion was measured and Tregs were defined using different protein markers.

Objectives: In this study, we measured both absolute numbers and proportions of CD4+CD25+Foxp3+ Tregs in peripheral blood of RA patients and investigated the effects of low-dose recombinant human IL-2 (rhIL-2) on Tregs and CD4+ effector T cell subsets in patients with RA.

Methods: Both absolute numbers and proportions of Treg and Th17 cells in peripheral blood, defined as the CD4+CD25+FOXp3+T or CD4+IL-17 + T cell population, were examined by flow cytometry in 342 patients with RA with different 28-joint Disease Activities (DAS28), including 75 who had never received disease-modifying antirheumatic drugs (DMARD) and 151 who were receiving or had received DMARD. Among these patients, 112 consented at enrollment to receive rhIL-2 treatment. Before and after treatment, the Th17 and Treg cells in peripheral blood were analyzed by flow cytometry.

Results: The absolute count of Treg cells in patients with RA was significantly low compared with that of healthy controls $(P<0.05)$, but the absolute count of Th17 cell was no different between RA and healthy controls. After the course of rhIL-2 treatment, there was a significant increase in the absolute count of Th17 and Treg cells in the CD4+ $T$ cell population $(P<0.01)$, but Th17/Treg was significantly low after the treatment.

Conclusions: The data suggest that, besides propotion, the decrease of Treg cell number, defined as the CD4+CD25+FOXp3+population, may contribute to the pathogenesis of RA. Over the treatment of rhlL-2, there was a more significant increase in the absolute count of Treg cells than that of Th17, and consequently restore the balance of Th17/Treg.

References:

[1] Miyara M, Ito Y, Sakaguchi S. TREG-cell therapies for autoimmune rheumatic diseases. Nature reviews Rheumatology 2014;10:543-51.

[2] Morita T, Shima Y, Wing JB, Sakaguchi S, Ogata A, Kumanogoh A. The Proportion of Regulatory $T$ Cells in Patients with Rheumatoid Arthritis: A Meta-Analysis. PloS one 2016;11:e0162306.

Disclosure of Interest: None declared

DOI: 10.1136/annrheumdis-2017-eular.2808

\section{SAT0214 AN ANALYSIS OF INCREASING SPACING TIME FOR THE INTRAVENOUS ADMINISTRATION OF TOCILIZUMAB IN} PATIENTS WITH RHEUMATOID ARTHRITIS

S. Ito ${ }^{1}$, D. Kobayashi ${ }^{1}$, C. Takai ${ }^{1}$, Y. Nomura ${ }^{1}$, A. Abe ${ }^{1}$, H. Otani ${ }^{1}$, H. Ishikawa ${ }^{1}$, A. Murasawa ${ }^{1}$, I. Narita ${ }^{2}$, K. Nakazono ${ }^{1}$. ${ }^{1}$ Niigata Rheumatic Center, Shibata; ${ }^{2}$ Division of Clinical Nephrology and Rheumatology Niigata University Graduate School of Medical and Dental Sciences, Niigata, Japan

Background: Although the biological disease-modifying antirheumatic drugs (bDMARDs) are the most effective treatment for rheumatoid arthritis (RA), the costs are much higher than those of conventional synthetic DMARDs. A number 